\title{
The “demonic forces” at Auschwitz: T. S. Eliot reads Jerzy Andrzejewski's Roll Call
}

On 2 November 1944 T. S. Eliot received a letter from Douglas Woodruff, the editor of The Tablet, written on behalf of his "Polish friend" Adam Żółtowski. Eliot was asked to write a foreword to "a little publication about the German Concentration Camp at Oświęcim [Auschwitz]." He replied in the affirmative, adding that though as a rule he wrote prefaces only to books published by Faber, in this case he might be ready to make an exception. This is how the correspondence between Eliot and Żółtowski, Director of the Polish Research Centre in London, began. ${ }^{2}$

This article traces the origin of the Auschwitz text, which I have identified as Jerzy Andrzejewski's Roll Call (Polish: Apel), and the journey it made from Nazi-occupied Warsaw to Eliot's desk in London. Since Eliot's preface to Roll Call did not appear in print in 1945, as originally planned, and remained unknown to the scholarly community for over seventy years, its recent publication in vol. 6 of The Complete Prose of T. S. Eliot, edited by David Chinitz and Ronald Schuchard, gives rise to a number of questions. ${ }^{3}$ One of them, which is discussed in this paper, is the absence of any references to Jews and Jewish suffering in both Andrzejewski's text and Eliot's preface. ${ }^{4}$ I also address the question of why the English edition of Roll Call with Eliot's preface was not published in 1945. To answer these questions, I examine unpublished correspondence between Eliot and Żółtowski within a wider context of wartime publishing and journalism. More specifically, I focus on Christian debates on the meaning of totalitarianism and religious narratives of World War II that dominated the political discourse of the 1940s. Thus, the paper aims to shed light on what Marina Mackay referred to as "the submerged relationships between modernism and political culture, where 'political' ... conveys its old meanings of parliamentary, journalistic and diplomatic discourses." ${ }^{5}$ To contextualise the unpublished translation of Roll Call and Eliot's 
preface within these discourses, I combine the examination of archival material with a review of historical documents, brochures, pamphlets, magazines and newspapers. By historicising the story behind Roll Call, the paper offers an interesting case study of wartime publishing. It raises important questions about the relationship between literary culture, religion, politics, and censorship in wartime Britain, and contributes to a better understanding of how the Holocaust was perceived and understood during World War II and in its immediate aftermath.

\section{Jerzy Andrzejewski's Roll Call and its journey to England}

When Eliot was writing the preface to Roll Call, he asked Żółtowski to give him more information about the author of the text and the circumstances in which it was written. Żółtowski responded that he did not know the name of the author, but confirmed that the text had come "from Poland by the usual channels," adding that he himself knew nothing about them and could not "ask to be told anything since human lives depend upon it being kept as secret as possible." ${ }^{\prime 6}$ While their letters do not contain any more detail about the origin of the text, they do reveal its English title: Roll Call. This and the timeline of the correspondence, together with the general summary of the text in Eliot's preface, make it possible to identify it as Jerzy Andrzejewski’s Apel, written in 1942 in Nazi-occupied Warsaw.

In 1942 Andrzejewski was already an established writer, which Eliot recognised in his preface, remarking that the author of Roll Call was "a man who knew how to write." ${ }^{77} \mathrm{He}$ began publishing short stories in 1932, and his first novel, Ład serca [The Heart's Harmony], won him the Polish Academy of Literature young writers' award in 1939. During the war, Andrzejewski took an active part in the resistance movement, distributing financial support 
among writers and artists on behalf of the Government Delegation for Poland (which was an agency of the Polish government-in-exile in London). In 1940, together with his close friend and future Nobel Prize winner Czesław Miłosz, he joined the underground socialist group Wolność [Freedom]. They both helped shelter Jews hiding from the Nazis. ${ }^{8}$ At the same time, Andrzejewski wrote short stories that were first published in the volume Noc [Night] in 1945. This included Wielki tydzień [Holy Week], a novella of the Warsaw Ghetto Uprising of 1943, and Apel [Roll Call]. ${ }^{9}$

Roll Call is set in the concentration camp in Auschwitz in the autumn of 1941 and tells the story of a roll call ordered as a collective punishment for a suspected escape of one of the inmates. The text opens with a matter-of-fact description of a typical day in Auschwitz:

The working day in the concentration camp of Oświęcim lasted twelve hours. It started at six o'clock in the morning with a roll call and ended at six o'clock in the evening with another. There was one more roll call at noon, the orchestra played and there was a dinner break. If for some infringement of the regulations the inmates of a particular block or the whole camp had to stand through a penal roll call in the evening, then the day, instead of having twelve hours, extended far into the night. ${ }^{10}$

In what follows the reader is introduced to some of the inmates: Warsaw student Stanisław Karbowski, high-school teacher Ignacy Śliwiński, medical doctor Parczewski, theatre actor Trojanowski, and those who are part of the camp administration: SS blockführer (block leader) Hans Kreutzmann, German kapo (prisoner functionary) Schreder, and Polish unterkapo (lower prisoner functionary) Nadolny. None of the characters are identified as Jews, which is historically justifiable - Roll Call was written in December 1942 and the story is set in the winter of 1941, before the mass deportations and extermination of Jewish people in Auschwitz began. ${ }^{11}$ 
One day the camp's routine is disrupted when Śliwiński fails to appear at the evening roll call. The SS-men order a special penal roll call, which is the main focus of the short story. All prisoners are forced to stand at attention in rainy autumn weather for fifteen hours, until Śliwiński is found dead in the basement of the building where he worked that day. Some of the inmates die of exhaustion or ill health, others are shot by SS-men, and yet others are forced to beat each other to death. After several hours, "the dull thud of people falling to the ground was heard more and more often." 12 The text gives the reader insight into the minds of some of the inmates and explores their thoughts in a liminal situation from which there is no escape. While the SS-men and functionaries are presented only from the point of view of the prisoners who observe their every movement with dread, quite unexpectedly one of them, Schreder, shows compassion to a dying prisoner. He kneels by him and holds his hand. It seems "as if the mask which he wore constantly" had disappeared and an "unusually beautiful and clear brightness" had lit his face. The scene takes just a moment (Schreder is quickly taken away by senior SS-men - "he was not shot on the spot only because he was a German"), but it breaks the strict division between the prisoners and the persecutors. ${ }^{13}$ Towards the end of the roll call, their voices merge to form a more universal expression of human degradation and suffering:

finally the shouts of the executioners and their victims became one human voice of torment, a voice which issued from the depths of darkness, hollow and without hope, like suffering itself and a fate lonelier than any other fate on earth. ${ }^{14}$

When the roll call was called off, the prisoners "looked like ghosts herded together to bear witness to the misery of the creature called man." 15

It is not clear how Andrzejewski, who was never imprisoned in Auschwitz himself, learnt so much about the camp as early as 1942 . It is likely that he had access to confidential 
underground reports about the camp, and he might have met people who were released or escaped from the camp. ${ }^{16}$ The event that Andrzejewski's text describes was identified by Auschwitz survivor Władysław Bartoszewski as the penal roll call of 28 October 1940: "We still do not know who told the story to Andrzejewski ... One thing is certain, and I find it surprising even today: Andrzejewski described that roll call as if he looked at it with my own eyes." 17

It is uncertain whether Andrzejewski knew that his text was sent to London and passed to Eliot. It is possible that he was not aware of it since Roll Call was brought to England in a clandestine military operation code-named Wildhorn III (Polish codename: Most III [Bridge III]). The primary aim of this mission was the transfer of a disassembled German V-2 rocket that had been recovered by the Home Army (the Polish underground) for examination in the UK. On 25 July 1944 a British aircraft flew from Brindisi in southern Italy, over the Balkans and into occupied Poland. Under the cover of the night, it was loaded with the missile components and on the return journey to Brindisi the crew was joined by four high-ranking members of the Polish resistance, who then made their way to London, carrying intelligence reports, as well as Andrzejewski's Roll Call. ${ }^{18}$

When the text was delivered to the Ministry of Information of the Polish governmentin-exile in London, it was decided that it would be translated into English and, if possible, published with a preface by a renowned British critic. ${ }^{19}$ As Żółtowski explained to Eliot, his "desire was that the name of the most outstanding British critic should testify to the British public, before whom the text is to be put, that the work is well worth reading." ${ }^{20}$ It was the official policy of the Polish Research Centre to approach British politicians, scholars and public figures with requests for endorsements and introductions that would assure the British reader that the brochures and pamphlets published by the Polish Research Centre were credible sources of information. ${ }^{21}$ What makes Roll Call's case exceptional, however, is the 
fact that hardly ever did the Ministry of Information spend their scarce resources, such as paper, which was strictly rationed throughout the war, on publications that did not have an

explicitly political value. ${ }^{22}$ Roll Call was one of only two literary texts to be published by them in English translation, and therefore an unprecedented decision was taken not to seek an endorsement from a political figure, but from a literary critic. ${ }^{23}$

\section{T. S. Eliot and Christian responses to the totalitarian challenge}

The letter Eliot received from Woodruff on 2 November 1944 stated that the Polish authorities decided to approach Eliot as "a Christian and a man of letters, sharing their general point of view, without being a co-religionist." 24 The letter does not state explicitly what general point of view Eliot shared with the Polish Research Centre, and why it was important that he was first a Christian and then a man of letters, but the answers to those questions can be inferred from the immediate political context. Eliot was approached in November 1944, three months before the Yalta Conference, at which Franklin D. Roosevelt, Winston Churchill and Joseph Stalin discussed the shape of post-war Europe and the future frontiers of Poland. Since the Soviet Union joined the Allies in 1941, the Polish authorities feared that the price for Stalin's support would be the Soviet control of Poland. By the end of 1944, it was clear that the UK and the US were more than likely to agree to Stalin's demands to install a Soviet-controlled puppet government in Poland, and the Polish government-inexile knew that they did not have much time left to act. ${ }^{25}$ The Polish authorities were desperate to win public support for the cause of independent Poland. It is in this context that we should view the planned publication of Roll Call. It was not meant to inform the reader of the current situation in Auschwitz (up-to-date intelligence reports were passed to the British 
government through official channels, and the opening paragraph of Roll Call makes it clear that the story is set in 1941), but to win wider sympathy for the Polish cause. ${ }^{26}$ It is not a coincidence that Żółtowski approached Eliot through the editor of The Tablet, a major Catholic weekly in Britain. ${ }^{27}$ By 1944, the most vocal opposition to communism and the Soviet Union came from the churches and the Christian press, and Eliot's was an important voice in these circles.

Eliot expressed his disapproval of both fascism and communism long before the war broke out. He regarded them as political systems that aimed to create substitutes for religion. In his 1932 BBC talk on "Christianity and Communism," he argued that "Russian communism is a religion" and urged his listeners to "keep in mind that you can never fight a religion except with another religion." 28 In 1933, in the opening talk of the Anglo-Catholic Summer School of Sociology, he maintained that "some forms of Fascism" and "some forms of Socialism" are heretical because their ambition is to build "an earthly paradise," which from a Christian point of view is unacceptable and utopian. "[A]ny general scheme of international harmony put forward as a substitute for religious unity," Eliot argued, "is likely to be more of a menace than a hope." 29

Eliot's view of totalitarianism as a challenge to religion that seeks to channel religious emotions and enthusiasm into a political cause was a common interpretation of the ways in which fascism and communism garnered widespread popularity. The thesis that fascism and communism should be viewed as "political religions" was put forward by various intellectuals, as well as the Christian press, and in 1938 expounded in much detail in Eric Voegelin's Political Religions. ${ }^{30}$ Jacques Maritain in his influential True Humanism, which was reviewed in The Criterion as "eminently worth reading and re-reading," argued that both communism and fascism were essentially anti-Christian: "the one and the other claiming for 
their temporal community that messianic love with which the Kingdom of God should be loved." 31

The view that the political turmoil could be resolved only on the spiritual plane was widely accepted among Christian intellectuals in Britain and regularly reiterated on the pages of the Catholic Tablet, Catholic Herald, Dublin Review, as well as the Anglican Church Times and The Guardian. Douglas Woodruff argued that the "great heresy of the twentieth century is political" since "[w]here men have no religious doctrine as a framework, there is a vacuum into which political ideas expand, swelling to monstrous sizes," and Eliot maintained that under the surface of "social and class impulses" there were "resources of violent religious passion" and the public intellectual's task was to "bring to the surface these true religious impulses." ${ }^{32}$ Eliot became closely associated with a number of groups that attempted to address these issues and propose ways in which the churches and Christian communities could counter the challenge of totalitarianism. This included the Christendom Group, the "Chandos" Group, the Moot and the circle of St Anne's House. He attended and spoke at major Anglican conferences, including the 1937 Oxford Conference on "Church, Community and State," and the 1941 Malvern Conference on the "Life of the Church and the Order of Society," and served on the editorial committee of the Christian News-Letter and the New English Weekly. ${ }^{33}$

It is noteworthy, however, that it was not only church leaders and the Christian press that defined Britain's war aims within a religious framework. Mainstream political figures resorted to similar language in their public speeches and parliamentary debates. ${ }^{34}$ On 1 September 1938, twenty-seven MPs signed an open letter to The Times in support of the movement of "Moral Rearmament." The letter stated that "in an age when lowered moral standards have become a breeding-ground for destructive forces," there was an urgent need for a moral renewal or "inner quickening." 35 In his broadcast of 14 July 1940, Winston 
Churchill declared that Britain was not fighting for herself alone, but the war was "of deep consequence to Christian civilisation." 36 Religious language was used in political discourse throughout the war. As Phillip Williamson observes, politicians who resorted to this type of vocabulary "drew upon the most powerful language available to sharpen and solemnize the confrontation with Germany" and to establish the role of Britain as the defender of Christianity. ${ }^{37}$ Presenting the war in religious terms served to give it a positive purpose: it was not only a war against Nazi Germany and Soviet Russia, but also a war for Christian Europe. Thus, even ostensibly secular newspapers and magazines, such as The Times, began to portray the war as "ultimately not material but spiritual" and as a fight for "not the mere fabric of civilization but its spirit and soul. ${ }^{38}$ It is within this context that Eliot was approached by Żółtowski. He was approached primarily as a Christian thinker and public intellectual who took a firm stance in religio-political debates, and whose views were well respected in the Christian circles.

\section{The Polish "test"}

How did the religious rhetoric of wartime discourse affect the way in which the information about occupied Poland and texts such as Roll Call were received, presented and discussed? Poland was invaded by Nazi Germany on 1 September and by Soviet Russia on 17 September 1939 and, thus, came to be perceived as a simultaneous victim of two "anti-Christian" aggressors. On the eve of the Nazi invasion, the New English Weekly referred to the Polish people as the "Messianic nation," which "can only set the house alight and perish, as a State, in conflagration" since the Poles "are a people enamoured of the idea of death and resurrection." ${ }^{39}$ A day after the invasion, The Tablet argued that Britain ought to honour the 
guarantee given to Poland, because Poland was "at once a test and a rampart" - "a test of sincerity of Herr Hitler's expression about a lasting understanding" and a rampart that will prevent Germany from ensuring "there is to be nothing left of the Christian faith." ${ }^{40}$ In the wake of the Soviet invasion, Poland was effectively presented as "a rampart between Naziism and Red Communism," a country that "repelled the onslaught of Bolshevism in 1920" and "the first nation to resist, by arms, the aggression of Hitlerism, with its paganism and deification of brutal tyranny." ${ }^{41}$ It was also a battleground that, from a wider perspective, symbolised the fate of Europe whose fragile peace settlements were simultaneously challenged by two different totalitarian regimes. "Everything which is happening in Poland today," pointed out The Tablet, "is a foreshadowing of the future in the west." 42 The threat that Nazi Germany and Soviet Russia posed to Poland and other European states was described through an explicitly religious imagery. "There is now an alliance between Bolshevist godlessness and Nazi devilishness, and who shall say which is worst?," asked the Church Times. ${ }^{43}$

This rhetoric had to be readjusted after the German invasion of Russia and Russia's joining of the Allies. Since the summer of 1941, the British Ministry of Information was keen to "avoid condemnation of the state atheism of the Soviet Union and to muffle criticism from other quarters," yet as Iain McLaine observes, the "attitude of Catholics continued to worry the authorities." 44 Much pressure was put on the Polish government-in-exile to avoid publicising information about the Katyń massacre and Soviet deportations of Polish citizens so as not to antagonise Stalin. ${ }^{45}$ By late 1944, the Polish authorities in London knew that the public opinion was looking forward to the end of the war. The issue of the Polish-Russian frontier and Poland's independence was not receiving much sympathetic coverage in the press. The Times accused the Polish authorities of attempting "to secure the aid of the Western Powers and to play off those Powers against Russia"46 instead of showing good will 
and accepting the settlement proposed by Stalin. In the House of Commons debate on the "Russo-Polish question” on 15 December 1944, the Polish government-in-exile was criticised for their "complete inability to get out of the world of make-believe in which they love to live" and their attempts "to mobilize Roman Catholic opinion throughout the world" to support Polish demands for sovereignty. ${ }^{47}$ By the end of 1944 it was almost only the Catholic and Anglican press that still showed support for the Polish cause and distrust of Stalin's intentions. ${ }^{48}$ The Tablet openly criticised the British government for their attempts "to whitewash what the Soviet does." 49 Towards the end of the war, Christian press again presented the issue of Polish independence as a "test" - this time it was a "test" for the integrity of the government's alleged Christian vision of the post-war reconstruction of Europe.

This discursive framework informed Eliot's understanding of the Polish situation and his reading of Roll Call. The fact that it was the editor of the Catholic Tablet who contacted Eliot on behalf of his "Polish friends" suggests that Eliot's specific religious beliefs were of less importance than his broader political conviction that communism was not a way forward for Europe ${ }^{50}$ Although Roll Call does not make any references to communism, it does show the dehumanising effect of the camp, which became an instrument of oppression and punishment used by both the Nazis and the Soviets. ${ }^{51}$ Thus in this specific political context, it does not come as a surprise that Eliot read the text as both an evidence that "Poland is the greatest sufferer among the nations," and a record that had a bearing on "the future of the whole of Europe." It showed the camp's "terrible congruity to the modern world" and "its aptness as an instrument for the demonic forces" that were at work to destroy the religious and cultural heritage of European civilisation. ${ }^{52}$ 


\section{The Extermination of the Jews in Christian discourse}

The absence of any references to Jewish suffering in Eliot's preface, which was written in December 1944, raises the question of his knowledge and understanding. With both Nazism and communism being understood as primarily anti-Christian ideologies, how did the Church communities and the Christian press react to the anti-Semitic policies of Hitler and the increasing number of reports on the extermination of Jews in occupied Europe? The Church of England took an official stance on racial discrimination at the Oxford Conference of 1937. The conference report argued for the removal of "racial barriers," calling attention to both "the colour bar in certain Churches" and "the more widely diffused and less acknowledged evil of anti-Semitism." 53 Throughout the war, many Church leaders campaigned against the Nazi persecution of Jews and tried to urge rescue efforts and combat domestic anti-Semitism. In December 1939, the Christian News-Letter, launched by the members of the Moot, stated that "the sufferings of the Jews are pre-eminent" and argued that the "future course of the world and of Christianity itself may be determined by the attitude which Christians take towards these issues." 54 In September 1941, the Christian News-Letter published Eliot's commentary on Vichy France, which referred to the persecutions of French Jews, declaring that "unless the French Church, and the Protestant bodies in France rise to protest, we must feel serious doubts about the way in which the revival of Christian France, advertised from Vichy, is to be carried out." 55 In January 1943, after the United Nations issued a joint declaration confirming that the reports of the mass murder of Jews in Europe were true and condemning the "bestial policy of cold-blooded extermination," the Bishops of England and Wales urged the government to act by declaring that it was "the duty of civilized nations ... to exert themselves to the utmost possible extent to provide a sanctuary" for Jewish refugees. ${ }^{56}$ The Christian News-Letter joined the bishops' appeal, stating that the "treatment 
of the Jews is so wanton in its cruelty, so naked and unashamed in its inhumanity, that to fail to meet it with such counter-action as is open to us would be to share in the degradation of humanity." 57

While all these statements and protests openly opposed anti-Semitic policies of the Nazis, they nevertheless did not challenge the perception of Nazism as an anti-Christian menace. Throughout the war the meaning of Nazism, Tom Lawson argues, "continued to be explained and understood in the threat National Socialism posed for the Christian world." 58 Nazism as well as Soviet communism were presented as quasi-religious systems that aimed to eradicate all religion and thus destroy European civilisation. The members of the Moot discussed anti-Semitic policies of the Nazis in a similar way. John Baillie argued that the "Nazi attitude to the Jew was not merely an ethical but a religious principle and needed a counter religion to oppose it" because one "could not refute it wholly on the basis of rational ethics." In a similar vein, Christopher Dawson claimed that "the existence of believing societies in a non-believing society was now threatened by the greater material integration of the modern state," which was "evident in the treatment of Jews and Christians by the Totalitarian States." 59 Jewish people were referred to as a religious group, and their persecution was viewed as part of a more universal assault on religion by totalitarian regimes. The Christian News-Letter maintained that the extermination of the Jews in Europe was a "crime not against the Jews alone, but against mankind." 60

The way Christian press addressed the Nazi extermination of European Jews has to be viewed within a larger context of wartime press coverage and political censorship. As Holocaust scholars have established, the British and American governments controlled what a wider public in these countries knew about the mass murder of Jews on the continent. ${ }^{61}$ They received intelligence reports from occupied countries, published official statements informing citizens of the developments in Europe, and orchestrated the production of propaganda 
material designed to raise the morale at the home front. The British Foreign Office policy stipulated that Jews were to be referred to as nationals of particular countries. The aim of this policy was to prevent the increase in the level of domestic anti-Semitism on the one hand, and to avoid pressure on the government to relax its strict refugee policy on the other. ${ }^{62}$ In 1940, the British government prevented G. B. Shaw from talking about the persecution of Jews in a public broadcast out of "fear of upsetting public opinion."63 Similarly, William Temple, the Archbishop of Canterbury, was instructed not to mention the word Jew in his April 1944 broadcast in which he appealed to Hungarian Christians to help the victims of Nazism. ${ }^{64}$ Tony Kushner argues that this way of framing the war narrative was directly related to the universalist liberal thinking of the British authorities who wanted to see all Jews as citizens of their countries of birth, and refused to define them by their ethnicity or race as Hitler did. As a 1944 Foreign Office document stated, the authorities refused to "regard Jews as belonging to a separate category" because "discrimination of this kind savour[ed] too strongly of the Nazi attitude towards Jews." 65 This kind of thinking, Kushner contends, led to a "reluctance to accept publicly the Jewish dimension of the Nazi atrocities" and thwarted attempts at an implementation of an effective rescue and refuge policy. ${ }^{66}$ The official stance taken by the British and American governments was that the rescue of European Jews would be achieved only through the liberation of occupied Europe. Drawing attention to Jewish suffering would go against this rationale, and it was believed that it could potentially "undermine British unity and increase anti-Semitism in Britain."67

Not surprisingly, such official narratives came to dominate the accounts published in British and American press. The wartime news circulation system followed what Michael Fleming calls a "voluntary" censorship regime, in which the press relied heavily on the reports issued by the government and maintained a large dose of scepticism towards statements and intelligence reports issued by foreign governments and international bodies 
whose veracity and reliability was not confirmed by the Foreign Office. ${ }^{68}$ Thus, despite the fact that throughout the war news agencies had constant access to relatively up-to-date information on the persecution and mass murder of European Jews, very rarely did such news make it to the first pages. Holocaust scholars such as Deborah Lipstadt, Laurel Leff, and Antero Holmila have concluded that the way the information about the ongoing extermination of the Jews was buried within the inside pages of mainstream newspapers had a key impact on how it was received by readers. ${ }^{69}$ Such positioning shaped the discursive environment of the (often competing) war narratives. With hindsight, it is not easy to establish whether the editors' and journalists' decisions to relegate such articles to inside stories were dictated by their own or the target reader's scepticism, disbelief, indifference or prejudice, yet it is clear that priority was given to the coverage of the national war effort:

During the war, the story was the prosecution of the war, the pursuit of an Allied victory. ... Their editors wanted stories about the home front and the war front. They were not geared for stories - quite fantastic stories - about millions of Jews being gassed and burned to death as part of a systematic German campaign to exterminate a people. $^{70}$

Another reason behind the editors' decision not to prioritise reports on the extermination of the Jews might have been their distrust of what they considered to be "atrocity propaganda," whose perceived aim was to incite hatred towards the Germans. This distrust stemmed from the propaganda legacy of World War I, which was exposed and criticised in the post-war years. Vernon McKenzie, a contemporary scholar of journalism, argued that "because certain widely-circulated, and for a time widely-credited, World War I atrocity tales were proved false, suspicion was cast on all atrocity reports."71 This unwillingness to believe that intelligence reports coming from occupied Europe were true created a barrier of understanding that activists who campaigned for the implementation of a 
more effective rescue plan, such as Eleanor Rathborne, Victor Gollancz or Arthur Koestler, found increasingly difficult to overcome. In January 1944, the New York Times published Koestler's article that desperately urged the reader to believe in the "grim stories of Nazi atrocities":

I have been lecturing now for three years to the troops.... They don't believe in concentration camps, they don't believe in starved children of Greece, in the shot hostages of France, in the mass graves of Poland; they have never heard of Lidice, Treblinka or Belzec. You can convince them for an hour, then they shake themselves, their mental self-defense begins to work and in a week the shrug of incredulity has returned like a reflex temporarily weakened by a shock. ${ }^{72}$

This attitude persisted even after the camps were liberated. Many early accounts of the liberation of the camps did not mention the fact that most of the Nazi victims were Jewish, referring to them as nationals of particular states instead. ${ }^{73}$ As Holmila observes, "the systematic nature of the Jewish tragedy, the uniqueness of the extent to which it was particularly Jews who had suffered, was virtually absent in the British press discourse" immediately after the war. ${ }^{74}$ Instead, the coverage focused on the Nazi perpetrators and the British and American liberators. "The objective of the British and American governments in revealing the nature of the crimes of their enemy had not been to focus on the victims of the Nazis (and especially not the Jews)," Kushner concludes, "but to emphasize the rightness of the war effort through the demonization of the German people." ${ }^{75}$

This lack of understanding of the Jewish plight was not limited to the issue of press coverage, but posed a deeper problem that affected the American and British treatment of Jewish displaced persons camps in Germany. ${ }^{76}$ In October 1945, 17,000 Jewish survivors in the DP camp in Bergen-Belsen undertook a hunger strike in protest against the systemic 
failure to recognise them as the group that was singled out for destruction by the Nazi regime. On 14 October, The Observer reported:

The Jews of Belsen have a special grievance. They are not recognised as a separate national, ethnical, or religious group. They are treated either like Poles or Hungarians. The motive of that treatment is undoubtedly just - British authorities refuse to introduce racial or religious discrimination. Yet this abstract principle fails to do justice to the reality here. The Jews have, in fact, suffered as Jews and not as Poles or Hungarians, and they have suffered incomparably more than non-Jews. ${ }^{77}$

As these examples show, the recognition of the special status of Jews as victims of Nazism was a slow and by no means straightforward process. The reluctance of the British and American governments and mainstream newspapers to address this question contributed to the wider public's ignorance.

The public understanding of what happened in Auschwitz-Birkenau in particular posed yet another problem. The camp was liberated on 27 January 1945 by the Soviet army, but most British and American newspapers reported on the liberation only in April/May 1945. While the concentration camps liberated by the American and British troops, including Belsen, Buchenwald and Dachau were considered major news items, the Soviets' liberation of death camps, such as Majdanek and Auschwitz-Birkenau, were "minor stories as far as the British press was concerned - doubted as Soviet atrocity-mongering and rarely connected to the Jewish disaster." ${ }^{78}$ Even if Soviet reports had been trusted, they would not have shed light on the Nazi extermination of Jewish people because they did not identify Jews as the primary victims. $^{79}$

There is, therefore, no contradiction in saying that British and American readers could have been simultaneously aware and ignorant of the plight of European Jews. They were 
aware that Jews were being persecuted, scapegoated and murdered in large numbers throughout the war, and yet at the same time they could have been ignorant of the systematic nature of the Nazi extermination programme. There was no shortage of information on the Nazi anti-Semitic policies, and yet the way in which this information was presented in newspapers, buried in the inside pages among other less important pieces of news, failed to convey the sense of tragedy that was unfolding in front of readers' eyes. "British and American citizens had no real comprehension of the scale of the Nazi slaughter," Fleming argues, "not because the data was not available to officials and newspaper editors, but because the US and the British governments and the "free" press decided it was not a central story of the fight against Nazi tyranny."

\section{Roll Call and the Mnemohistory of the Holocaust}

Why did Eliot, when speaking of the evil of "treating any group of human beings ... as something less than human, as merely pawns or pests" in December 1944, not mention Jews and focused only on the suffering of Poles? It is possible that, just like most British public, he was not fully aware of the Jewish plight. And yet, in his preface Eliot refers to the "lurid account[s] in the daily press." ${ }^{81}$ When Żółtowski sent Eliot the typescript of Roll Call, he was eager to assure him that the text was "something more than the general run of atrocity reports," assuming that Eliot would find it difficult to believe that the events described in the text really took place. ${ }^{82}$ In the same letter Żółtowski vouched that the text "has been brought from occupied Poland" and that was the proof of its "undoubted authenticity." When Eliot enquired about more details regarding the text's origin, Żółtowski, perhaps concerned that Eliot may disbelieve the text's authenticity, offered to arrange a meeting between Eliot and 
his cousin who "passed more than three years in seven different camps and also knows the one at Oświęcim where his father died." ${ }^{, 83}$ While Eliot accepted Żółtowski’s assurance, he nevertheless insisted that "there should be some statement about the origin of the manuscript, or some readers will presume it to be simply a brilliant piece of imaginative fiction." 84 Thus, as late as December 1944, Eliot gave an expression to a widespread disbelief in atrocity stories and reports coming from occupied Europe.

Eliot and Żółtowski shared an understanding that what Żółtowski referred to as the "general run of atrocity stories" had made the general reader sceptical and doubtful, and Roll Call would appeal to the British audience only if it could offer something more than what they had become used to. According to Eliot, Andrzejewski succeeded in doing that:

He makes us feel the degree to which suffering isolates men each in his private hell: yet his sympathy and compassion unite the characters in a communion of misery. The compassion almost extends to the torturers themselves: they too, like the prisoners, are isolated from each other, and yet torturers and tortured all exist in one hell together. In short, the author writes with detachment .... In so doing, he enables us to experience the abomination, as the most lurid account in the daily press cannot do. ${ }^{85}$

Eliot's remarks suggest that what made the text special was its attempt to address the issue of suffering from a perspective wider than the victims' - a perspective that embraced also those who inflicted suffering, that showed the perpetrators and the tortured "in a communion of misery." Such a perspective was obviously absent from the articles published in the daily press, where the perpetrators would be clearly identified as the Germans, and the victims as the nationals of occupied countries. Instead of providing numbers of victims and statistics, Roll Call focused on a single incident and offered an insight into the dehumanising effects of the camp. It did not directly put the blame on the Germans, but rather pointed to the horror of 
the situation in which human beings inflicted terrible and pointless suffering on each other. In other words, the text invited a more general and abstract reflection on what the camp did to people - both those who were imprisoned in it and those who ran it. Eliot's reflection that "however the concentration camp comes about, it inevitably brutalises those who keep it and those who countenance it" seems to be a direct commentary on Andrzejewski's attempt to show that camp functionaries were still capable of human reactions. ${ }^{86}$ Similarly, Eliot's universalist reading of the camp as "an instrument for the demonic forces" (as opposed to the understanding of the camp as an instrument used by the Nazi regime to annihilate Europe's Jewish population) corresponds to Andrzejewski's description of the camp as "hell" that concentrates together "all human hatred and all the cruelty of the world." 87

In the end, the English translation of Roll Call with Eliot's preface was not published in 1945 as planned. Whatever happened to the text was most likely related to the immediate political situation. On 14 March 1945 Żółtowski informed Eliot that the English translation with his preface would be published by the London-based Polish literary journal Nowa Polska [New Poland], but it never appeared in print with Eliot's preface. ${ }^{88}$ It is worth noting, though, that after the publication of Roll Call was dropped, a concentration camp testimony that came from Poland was published in John Middleton Murry's Adelphi. The April-June 1947 issue included Eugenia Kocwa's Ravensbrück memoir “On the Sands of Mecklenburg," which was brought to London by Margaret Storm Jameson. Storm Jameson went on a ten-day visit to Warsaw and Kraków as a member of PEN International, accompanied by Antoni Słonimski, the editor of Nowa Polska, in September $1945 .{ }^{89}$ In Kraków she met Kocwa, who told her of her four-year imprisonment in Ravensbrück, and passed her a memoir she published in a Polish journal. ${ }^{90}$ The memoir was subsequently translated into English by Maria Kuncewiczowa and published in The Adelphi with Storm Jameson's introduction. ${ }^{91}$ Both the introduction and the other articles and reviews published in this issue show how the 
Christian framework used to interpret what happened in the concentration camps could obscure the Jews' plight as late as two years after the end of the war.

The April-June 1947 issue featured three articles by the members of the Moot (Eliot, Murry, Hodges), who all reflected on the perceived crisis of European culture and civilisation, as well as book reviews that addressed the question of post-war reckoning. The issue put forward a clearly delineated narrative on how to understand what happened during the war and how best to move forward and work towards post-war reconstruction. Hodges' opening article, "The Crisis of Western Culture," identified the crisis as having several dimensions: social, cultural and spiritual, and argued that Marxism's menacing power to "transform the consciousness of mankind" was being underestimated. ${ }^{92}$ The article contended that "as the Nazis regarded non-Aryan man as an inferior type, so the communist must regard pre-socialist man as an undeveloped and in that sense inferior type." 93 The following article, Eliot's "Culture and Politics," lamented the "gradual closing of the mental frontiers of Europe" and argued against confusing culture with politics. "An error of the Germany of Hitler," Eliot observed, "was to assume that every other culture than that of Germany was either decadent or barbaric." 94 Murry's "The Crisis of Man," written partly in response to Hodges' and Eliot's articles, contended that the crisis they were trying to diagnose was in fact "a crisis of the human spirit - of the human mind, the human intelligence, the human conscience." ${ }^{95}$ Thus, while Hodges, Eliot and Murry did not agree on all the details, the core of their diagnoses remained essentially the same: Europe's culture(s) and its political scene were in need of regeneration. This regeneration, however, could not be brought about by Soviet Russia, which was seeking to subjugate other (Christian) cultures, and in this sense implementing what they considered the Nazi model. 
It is within this context that the reader was invited to engage with Kocwa's text - it was printed immediately after Murry's article. In her introduction to Kocwa's memoir, Jameson described her meetings with the author:

When I saw her for the second time she told me that she had spent years in Ravensbrück concentration camp. ... Her eyes, very clear, had an expression I was beginning to recognise - I had seen it in the eyes of other survivors. They were inward-looking. Their direct glance came from a depth. Looking at me from her still depth, she said: "In Ravensbrück I learned to live. I became a Christian, because I found that only God could help.",96

Kocwa's account is framed in a very specific context - that of unspeakable suffering which could be alleviated only by Christianity - and can well be read as a reflection on the crisis that Hodges, Eliot and Murry analysed in their articles. Kocwa describes the world of Ravensbrück as a space in which Christian values have been maliciously upturned:

Here, as in some diabolical theatre, all notions are reversed. Everything that, when we were free, was good is now bad, and vice versa. To be kind is clumsiness, to be honest, stupidity, to be brutal is the height of efficiency. Everything that shows compassion or a warm heart is forbidden. Most strictly are handshakes and kisses. You are not allowed to take anyone's arm, you are not allowed to make the sign of the Cross. $^{97}$

The camp is presented as an anti-Christian world in which the inmates who do not learn the new rules fast enough are not able to survive.

Traumatic as this experience was, according to Jameson, Kocwa insisted that she had to forgive those who inflicted this suffering on her. "She said: 'We suffered so terribly that I do not think of punishment for our tormentors. Such things can only be forgiven, and they 
must be forgiven." 98 In this way both the crime and the need to forgive and not to pursue retribution are framed within a larger Christian narrative that sought to argue that to move forward one must not seek revenge, but offer forgiveness. The notion of forgiveness as a healing practice is further developed in J. P. Hogan's review of Victor Gollancz's In Darkest Germany and Stefan Schimansky's Vain Victory, which focused on the suffering of German deportees. ${ }^{99}$ Hogan observed that such books enabled the British reader "so uncomfortably exempt from extremity of hardship even now, to suffer at least in imagination along with the German people." He concluded his review stating:

We live in the same world as Eugenia Kocwa describes; it is mere accident that we have been more fortunate so far. When the time comes we must meet devilry and destruction with a passionate sainthood. Meanwhile we have our concern, our deepening responsibility, our burden of guilt; we do not lack occasion and opportunity for atonement. ${ }^{100}$

No doubt this narrative of pain that was inflicted by the "devilry" of totalitarianism and that ought to be met with forgiveness and sainthood offered a way of coping with the trauma to some of the survivors, including Kocwa. Nevertheless, it left the Jewish suffering out of the picture. The entire issue of The Adelphi devoted to the crisis of Europe, published as late as 1947, did not contain a single reference to the mass murder of Europe's Jews. None of the articles or reviews nor Kocwa's account mentioned Jews as victims, focusing on a more universal understanding of suffering and considering the camps as, in Eliot's words, "an admonition for the future."101 Such a treatment of the topic was in fact symptomatic of postwar Christian narratives. As Lawson points out, a recognition that Jews were "the primary victims of Nazism would have challenged the basis of this entire mindset by introducing the idea that Nazism was something other than simply the negation of Christianity, and the denial of a Christian God."102 
One possible reason why Roll Call was not published in 1945 is that it was withdrawn from publication after the news of the liberation of Auschwitz came to light. In the summer of 1945, when the translation with Eliot's preface was scheduled for publication, Nowa Polska, which until then appeared monthly, was hit by paper shortage and after the June issue came out, the journal was shut down for three months. ${ }^{103}$ In the meantime, Słonimski, the editor-in-chief, visited Poland with Storm Jameson and several other delegates. The visit made him aware not only of the scope of destruction, but also of the high level of antiSemitism and hostility towards Jewish survivors among Poles. ${ }^{104}$ This may have been the reason why, when Nowa Polska resumed publication after its paper license was renewed, a number of pieces in the October 1945 issue explicitly addressed the mass extermination of Jews. ${ }^{105}$ Słonimski might have decided against publishing Roll Call and Eliot's preface precisely because they did not highlight the Jewish tragedy, focusing only on the suffering of Poles. ${ }^{106}$ As Storm Jameson recounts, during their visit to Poland Słonimski was "unhappy and disappointed" with what he saw, and while he acknowledged the existence of "the heroic side" of Poles, he drew Jameson's attention to "other things which are not heroic," in particular the post-war resurgence of anti-Semitism. ${ }^{107}$ The visit to Poland could have influenced Słonimski's selection of texts to be published by Nowa Polska, and his decision to print texts that highlighted the Jewish tragedy could well be read as a political statement.

It is also possible that the text was withdrawn from publication for strictly political reasons. Since Auschwitz-Birkenau was liberated by the Red Army on 27 January 1945, which was reported in the Western media in April/May, it would have been difficult to publish the English edition of Roll Call without referring to that fact. In his preface, Eliot states that "there are concentration camps still on Polish soil, as there are in Germany itself." 108 While this was true in December 1944, after the liberation such a statement would have to be qualified with an appropriate note. For the Polish government-in-exile the Soviet 
liberation was simultaneously a new occupation, which meant that they might have been reluctant to publish a book that would have, however indirectly, paid tribute to the Soviet army. ${ }^{109}$ The Polish edition of Apel published in London in July 1945 was introduced by resistance officer Andrzej Pomian, who was airlifted from Poland in April 1944. ${ }^{110}$ Interestingly, his preface does not make a single reference to the Soviet liberation of Auschwitz. It ends on a bleak note, confirming that "Warsaw is not free yet." 111 The Polish reader would have been able to read between the lines, yet the fact that Pomian did not refer to the Red Army's presence on the Polish soil was quite symptomatic of the Allied-imposed silence on the topic of the Soviet takeover of Poland. Since the breakdown of Polish-Soviet diplomatic relations in 1943, the British government made sure that "every Polish issue was viewed ... in the light of Soviet sensibilities." 112

What the English translations of Roll Call and "On the Sands of Mecklenburg" and Eliot's and Storm Jameson's prefaces demonstrate is that the universalist Christian understanding of the war as a fight against totalitarian godlessness minimized the Jewish tragedy. It is important to bear in mind that these two texts were by no means exceptional cases. Rather, they are examples of a relatively common post-war understanding of what later came to be known as the Holocaust. In the mid-1940s, the idea that Jews were the primary victims of Nazism was either downplayed or completely absent from public discourse. As Aleida Assmann points out, "it took two decades before the event was identified by name, and a discourse evolved on the unprecedented magnitude of the trauma and crime."113 Therefore Anthony Julius' argument that at the time "Eliot did not understand the Holocaust as an event in the history of anti-Semitism" is probably true. ${ }^{114}$ Indeed, not many people in the 1940s understood it that way. While the Holocaust has come to be considered "the paradigmatic genocide in world consciousness," a closer look at its "mnemohistory" reveals that the full knowledge and understanding of what happened to the Jewish population of 
Europe was not immediate. ${ }^{115}$ While today this may seem hardly conceivable, in the post-war years the Holocaust was treated as merely a "footnote to the Second World War," and therefore it should not come as a surprise that the literary culture of the time reflected and shared in this understanding. ${ }^{116}$

\section{Acknowledgements}

I gratefully acknowledge the generous support of the Irish Research Council's Postdoctoral Research Fellowship. I would like to extend my sincere thanks to Robert Brown (Faber Archive), Michael Fleming (PUNO), Jadwiga Kowalska (PISM), Ronald Schuchard (Emory University), Małgorzata Wichowska (Museum of Literature in Warsaw), and Krystyna Zatylna (PUMST).

\footnotetext{
${ }^{1}$ The correspondence between Żółtowski, Eliot and Woodruff is part of the Polish Research Centre Collection (434/124) held at the archive of the Polish Institute and Sikorski Museum in London. All subsequent quotations are from this correspondence. Auschwitz is the German name for Oświęcim. I use the name Auschwitz as this is the standard way to refer to the camp in English-language scholarship.

2 Żółtowski, one of the Centre's founders, was among the scholars who went into exile in 1939, when Poland was invaded by Nazi Germany. Before the war, he lectured in philosophy at the University in Poznań, and worked for the Polish Ministry of Foreign Affairs. In London, he acted as Director of the Polish Research Centre, and lectured at Polish University College.

${ }^{3}$ T. S. Eliot, "Preface to Roll Call," in The Complete Prose of T. S. Eliot: The Critical Edition, vol. 6, ed. Ronald Schuchard and David Chinitz (Baltimore: Johns Hopkins University Press, 2017), 581-585.

${ }^{4}$ The answer to this question may have significant implications for the ongoing debate on Eliot's anti-Semitism. See "Special Section: Eliot and Anti-Semitism: The Ongoing Debate," Modernism/modernity 10, no. 1 (2003): 1-70 and 10, no. 3 (2003): 417-54; Jason Harding, The Criterion: Cultural Politics and Periodical Networks in Inter-war Britain (Oxford: Oxford University Press, 2002), 143-158; Anthony Julius, T.S. Eliot, Anti-Semitism and Literary Form (London: Thames\&Hudson, 2003).

${ }^{5}$ Marina Mackay, Modernism and World War II (Cambridge: Cambridge University Press 2007), 14.

${ }^{6}$ Letters of 8 and 12 December 1944.

${ }^{7}$ Eliot, "Preface to Roll Call," 582.

${ }^{8}$ Anna Synoradzka, Andrzejewski (Kraków: Wydawnictwo Literackie, 1997), 40-74.

9 Jerzy Andrzejewski, Noc: Opowiadania [Night: Short Stories] (Warszawa: Czytelnik, 1945). Wielki tydzień was published in English as Holy Week: A Novel of the Warsaw Ghetto Uprising, trans. Oscar Swan (Athens: Ohio University Press, 2007). The Polish edition of Apel was also published anonymously in London in 1945 , Hannover in 1946 and in Rome in 1947. The original typescript is part of the Andrzejewski Collection (1522), Archive of the Museum of Literature in Warsaw.

10 Since the translation that Eliot read has not been found, all quotations are given from the first published English translation of Apel: Jerzy Andrzejewski, "Roll Call," trans. anon., Poland: Illustrated Magazine 71 (1960): 13-28.
} 
11 The first quick death camp for Jews was established in Kulmhof-am-Nehr (Chełmno nad Nerem) in the Wartegau (Wielkopolska) region incorporated into the Third Reich in December 1941. The first mass transports of Jews arrived in Auschwitz in March 1942. See Peter Longerich, Holocaust: The Nazi Persecution and Murder of the Jews (Oxford: Oxford University Press, 2010), 313-373.

12 Andrzejewski, "Roll Call," 28.

${ }^{13}$ Ibid.

${ }^{14}$ Ibid.

15 Ibid.

${ }^{16}$ Andrzejewski took part in the resistance since 1941, distributing financial support among writers and artists on behalf of the Ministry of Culture in the Government Delegation for Poland, which was an agency of the Polish government-in-exile. In 1940, together with Czesław Miłosz, who was his close friend at the time, he joined the underground socialist group Wolność [Freedom]. Synoradzka, Andrzejewski, 53-6; Czesław Miłosz, Zaraz po wojnie: Korespondencja z pisarzami 1945-1950 [Just After the War: Correspondence with Writers 1945-1950] (Kraków: Znak, 1998), 21.

${ }^{17}$ Władysław Bartoszewski, Mój Auschwitz [My Auschwitz] (Kraków: Znak, 2012), 39-40. Although Apel tells the story of the roll call of 28 October 1940, it is set in the autumn of 1941, which might have been either Andrzejewski's mistake, or a result of his decision to move the time of the narrative forward. Two years after Andrzejewski wrote Apel, his parents were deported to Auschwitz after the outbreak of the Warsaw Rising. His father, Jan Andrzejewski, escaped during the camp's evacuation. His mother, Eugenia Andrzejewska, was sent to Ravensbrück, where she died. Synoradzka, 73, 77.

18 The documents were received in London on 30/31 July 1944. The list of contents referred to Andrzejewski's text as "“Apel”: accounts from Oświęcim - typescript” (Archive of the Polish Underground Movement Study Trust in London, A377/264 and A378/50). For more detail on Operation Wildhorn, see Jonathan Walker, Poland Alone: Britain, SOE and the Collapse of the Polish Resistance, 1944 (Stroud: The History Press, 2008), 86-113.

${ }^{19}$ The name of the translator of Apel remains unknown.

${ }^{20}$ Letter of 27 December 1944.

${ }^{21}$ Throughout the war, the Polish Research Centre issued a series of English-language books and pamphlets on Polish history, culture, and current political situation. The MPs who endorsed the PRC's publications included Philip Noel-Baker (preface to Underground Poland Speaks, 1941), Vernon Bartlett (Unknown Europe, 1942), Josiah Wedgwood (Stop Them Now, 1942), Arthur Greenwood (Towards a New Poland, 1942), Thelma Cazalet-Keir (In Hell, 1944), and Jennie L. Adamson (The Camp of Death, 1944).

${ }^{22}$ For a comprehensive discussion of wartime publishing and paper rationing, see Valerie Holman, Print for Victory: Book Publishing in England 1939-45 (London: British Library, 2008).

${ }^{23}$ The other such publication was Aleksander Kamiński's novel Stones for the Rampart (Polish: Kamienie na szaniec), which tells the story of the Polish scouts' resistance against the Nazi regime. After the book was brought into the UK in April 1944, Jan Baliński-Jundziłł, deputy director of the Polish Research Centre, asked Percy Hugh Beverley Lyon, educator and headmaster of Rugby School, to write a short introduction to the English translation. Lyon agreed, though with a reservation that he had to "avoid committing [him]self to any public expression of political opinion, or even to opinions which might be regarded as political by prejudiced persons," and with a recommendation that the Russian invasion of Poland of 1939 should not be described as a "stab in the back." The book was published pseudonymously in London in 1945 in two editions: English (with Lyon's preface) and Polish (with the Polish Prime Minister Tomasz Arciszewski's preface). Juliusz Górecki [Aleksander Kamiński], Stones for the Rampart: The Story of Two Lads in the Polish Underground Movement (London: Polish Boy Scouts' and Girl Guides' Association, 1945); Juliusz Górecki [Aleksander Kamiński], Kamienie na szaniec (London: Światpol, 1945). The correspondence is part of the PRC Collection 434/193 (PISM).

${ }^{24}$ Letter of 2 November 1944.

25 The UK and the US withdrew their recognition of the Polish government-in-exile in London and officially recognised the Communist-controlled government in Warsaw in July 1945.

${ }^{26}$ For an in-depth discussion of the intelligence reports on Auschwitz that were sent from occupied Poland and passed to the British government, see Michael Fleming, Auschwitz, the Allies and Censorship of the Holocaust (Cambridge: Cambridge University Press, 2014).

${ }^{27}$ Douglas Woodruff's sympathy for the cause of independent Poland was recognised and appreciated by the Polish authorities. In September 1944 he was awarded the Order of Polonia Restituta. He declined it, explaining that he believed that journalists "should forego these public honours" and remain "independent and, without fear or favour, support people when we believe them to be in the right." The PRC Collection 434/365 (PISM).

${ }^{28}$ T. S. Eliot, "Christianity and Communism," in The Complete Prose of T. S. Eliot: The Critical Edition, vol. 4, ed. Ronald Schuchard and Jason Harding (Baltimore: Johns Hopkins University Press, 2015), 422-31 (424). 
${ }^{29}$ T. S. Eliot, "Catholicism and International Order," in The Complete Prose, vol. 4, 534-46 (538-9). See also Eliot's exchange with R. Pierce-Butler in the Church Times: R. Pierce-Butler, "Fascism and Christianity," January 26, 1934, 84; T. S. Eliot, “The Blackshirts,” February 2, 1934, 116.

30 Eric Voegelin, Die politischen Religionen (Vienna: Bermann-Fischer, 1938). English translation: "The Political Religions," trans. Virginia Ann Schildhauer, in The Collected Works of Eric Voegelin, vol. 5: Modernity Without Restraint, ed. Manfred Henningsen (Columbia: University of Missouri Press, 2000), 19-73. See also Emilio Gentile, Politics as Religion, trans. George Staunton (Princeton: Princeton University Press, 2006), 45-109.

${ }^{31}$ Jacques Maritain, True Humanism, trans. M. R. Adamson (London: The Centenary Press, 1938), 272; Philip S. Richards, "Review of True Humanism by Jacques Maritain," The Criterion 18, no. 71 (January 1939): 329-22 (329). True Humanism was selected as "the basis for the work of the Moot," which Eliot joined in 1938, and it was referenced by Eliot in the preface to The Idea of a Christian Society. The Moot Papers: Faith, Freedom and Society 1938-1944, ed. Keith Clements (London: Bloomsbury, 2009), 145; T. S. Eliot, The Idea of a Christian Society and Other Writings (London: Faber, 1982), 42.

32 Douglas Woodruff, "Religion and Patriotism," The Sword of the Spirit Bulletin 44, April 16, 1942: 1-2 (1); The Moot Papers, 114.

${ }^{33}$ See Roger Kojecky, T. S. Eliot's Social Criticism (London: Faber, 1971), 126-197; Stefan Collini "The European Modernist as Anglican Moralist: The Later Social Criticism of T. S. Eliot," in Enlightenment, Passion, Modernity: Historical Essays in European Thought and Culture, ed. Mark S. Micale and Robert L. Dietle (Stanford: Stanford University Press, 2000), 207-229; and Steve Ellis, British Writers and the Approach of World War II (Cambridge: Cambridge University Press, 2015), 17-65.

${ }^{34}$ Just before the outbreak of the war, the British Ministry of Information set up the Religions Division, and soon afterwards launched its weekly bulletin The Spiritual Issues of the War. See Ian McLaine, Ministry of Morale: Home Front Morale and the Ministry of Information in World War II (London: Allen\&Unwin, 1979), 137-216.

35 "Moral Rearmament," The Times, September 10, 1938, 6. See also Moral Rearmament: The Battle for Peace, ed. H. W. Austin (London: Heinemann, 1938). While the movement enjoyed great public support, Eliot and other members of the Moot disapproved of it, considering it a misunderstanding and shallow revivalism. See Eliot, The Idea of a Christian Society, 95; and The Moot Papers, 98.

${ }^{36}$ Winston Churchill, Into the Battle (London: Cassell\&Co, 1943), 248-9.

${ }^{37}$ Philip Williamson, "Christian Conservatives and the Totalitarian Challenge, 1933-40," English Historical Review 115, no. 462 (2000): 607-42 (608).

38 "The Nation at Prayer," The Times, September 30, 1939, 7.

39 "Notes of the Week," New English Weekly, August 31, 1939, 247.

40 “The Supreme Issue," The Tablet, September 2, 1939, 296.

${ }^{41}$ Monica M. Gardner, "Poland has not perished," The Tablet, September 30, 1939, 402.

42 "The Threat to Poland," The Tablet, September 16, 1939, 352.

43 "Summary," Church Times, September 29, 1939, 263.

${ }^{44}$ McLaine, Ministry of Morale, 213-4.

${ }^{45}$ See Eugenia Maresch, Katyn 1940: The Documentary Evidence of the West's Betrayal (Stroud: The History Press, 2010).

46 "Widening Gap," The Times, November 27, 1944, 5.

${ }^{47}$ House of Commons Debates, December 15, 1944, vol. 406, cols 1490-4.

${ }^{48}$ See, for instance, Blackfriars, Special Issue on Poland (July 1944); "Summary," Church Times, November 3 , 1944; "The World Week by Week," The Tablet, January 6, 1945, 2.

49 “The World Week by Week," The Tablet, December 16, 1944, 290.

${ }^{50}$ From a religious perspective, Eliot could not be said to have shared Roman Catholic Żółtowski's point of view as he was critical of Polish Catholicism with its "blind Ultramontane devotion to the Papacy." The Letters of T. S. Eliot, vol. 3: 1926-1927, ed. Valerie Eliot and John Haffenden (London: Faber, 2012), 756.

51 The Soviet camps are described in detail in The Dark Side of the Moon, which was published anonymously with Eliot's preface by Faber in 1946. The book tells the story of the Soviet occupation of Poland in 1939-45. It was written by Zoe Zajdler, who fled from Poland at the outbreak of the war. On her arrival in London, she began working with the Polish government-in-exile, and was given access to reports from occupied Poland, which she used while writing The Dark Side of the Moon.

52 Eliot, "Preface to Roll Call," 583-4.

53 The Churches Survey Their Task: The Report of the Conference At Oxford, July, 1937, On Church, Community, And State (London: Allen\&Unwin, 1937), 184. The conference was attended by Eliot and a number of prominent Christian thinkers, and inspired J. H. Oldham to launch the Moot, a discussion group that met regularly from 1938 to 1947. Its members included leading Christian intellectuals of the time, including Eliot, 
John Middleton Murry, Christopher Dawson, and H. A. Hodges, as well as refugee scholars Karl Mannheim and Alfred Löwe. The Moot Papers, 6-24.

${ }^{54}$ Christian News-Letter 6, December 6, 1939. It included a supplement "The Fate of the Jews" written by Rev. James Parker. The Christian News-Letter was edited by Oldham, Eliot, Alec Vidler, Walter Moberly and Eleanora Iredale. By early 1940, the News-Letter had over 10,000 British and international subscribers and inspired the formation of many local discussion groups (The Moot Papers, 248).

${ }^{55}$ Christian News-Letter 97, September 3, 1941. Reprinted as "Freedom in Wartime," in The Idea of a Christian Society, 127-31.

56 "Refuge for Jews in the Empire: Bishops' Appeal to the Government," The Times, January 25, 1943, 2.

${ }^{57}$ Christian News-Letter 173, February 17, 1943.

58 Tom Lawson, The Church of England and the Holocaust: Christianity, Memory and Nazism (Woodbridge: Boydell Press, 2006), 91.

${ }^{59}$ The Moot Papers, 104, 420.

${ }^{60}$ Christian News-Letter 173, February 17, 1943.

61 See Fleming; Louise London, Whitehall and the Jews, 1933-1948: British Immigration Policy, Jewish Refugees and the Holocaust (Cambridge: Cambridge University Press, 2000); and David S. Wyman, The Abandonment of the Jews: America and the Holocaust (New York: Pantheon Books, 1984).

${ }^{62}$ As Michael R. Marrus points out, "[t]o the world outside Nazi-occupied Eastern Europe and even to many Nazi officials, the Jewish question in the first two years of the war was largely a question of refugees." Unwanted: European Refugees in the Twentieth Century (Oxford: Oxford University Press, 1985), 227.

${ }^{63}$ Tony Kushner, "Different Worlds: British perceptions of the Final Solution during the Second World War," in The Final Solution: Origins and Implementation, ed. David Cesarani (London: Routledge, 1994), $246-67$ (251). ${ }^{64}$ Lawson, The Church of England and the Holocaust, 93.

65 A response of the Foreign Office to Chief Rabbi's request for the Jews of Hungary to be given British protection in the summer of 1944, Public Records Office, Kew, FO 371/42811 WR 457, cited in Tony Kushner, "Rules of the Game: Britain, America and the Holocaust in 1944," Holocaust and Genocide Studies 5, no. 4 (1990): 382-402 (395).

${ }^{66}$ Kushner, "Rules of the Game," 395.

${ }^{67}$ Fleming, 71. See also London, Whitehall and the Jews, 161-251.

${ }^{68}$ Fleming, 75-6, 93.

${ }^{69}$ Deborah E. Lipstadt, Beyond Belief: The American Press \& the Coming of the Holocaust 1933-1945 (New York: Free Press, 1986); Laurel Leff, Buried by the Times: The Holocaust and America's Most Important Newspaper (Cambridge: Cambridge University Press, 2005); Antero Holmila, Reporting the Holocaust in the British, Swedish and Finnish Press, $1945-50$ (Basingstoke: Palgrave, 2011). See also Why Didn't the Press Shout? American and International Journalism During the Holocaust, ed. Robert Moses Shapiro (Jersey City: Yeshiva University Press, 2003).

${ }^{70}$ Marvin Kalb, "Journalism and the Holocaust, 1933-1945," in Why Didn't the Press Shout?, 1-13 (8).

71 Vernon McKenzie, “Atrocities in World War II - What We Can Believe," Journalism \& Mass Communication Quarterly 19, no. 3 (September 1942): 268-276 (269). See also Mackay, 11.

${ }^{72}$ Arthur Koestler, "The Nightmare That Is a Reality," The New York Times, January 9, 1944, 5.

73 See, for instance, "S.S. Regime of Terror at Belsen Camp," The Observer, April 22, 1945, 1, 5; and “4,000,000 Deaths at Oswiecim Camp," The Times, May 8, 1945, 5.

${ }^{74}$ Holmila, Reporting the Holocaust, 33.

75 Tony Kushner, The Holocaust and the Liberal Imagination: A Social and Cultural History (Chichester: Wiley-Blackwell, 1995), 218.

${ }^{76}$ See Angelika Königseder, Juliane Wetzel Waiting for Hope: Jewish Displaced Persons in Post-World War II Germany, trans. John A. Broadwin (Northwestern University Press, 2001), 15-41.

77 "17,000 in Belsen Hunger Strike: Jews Fight for Their Rights," The Observer, October 14, 1945, 5. See also Joseph H. Hertz, "German Horrors," The Times, May 28, 1945, 5.

${ }^{78}$ Kushner, "Different Worlds," 256.

79 As Dan Stone explains, "the Soviets wanted to portray the defeat of fascism as a victory for international working-class anti-fascism and to represent Nazism's victims as people who had died in the name of the antifascist cause - a notion that was incompatible with the fact that the Nazis' primary victim group was targeted on 'racial' grounds." Liberation of the Camps: The End of the Holocaust and Its Aftermath (New Haven: Yale University Press, 2015), 32.

${ }^{80}$ Fleming, 277.

${ }^{81}$ Eliot, "Preface to Roll Call."

${ }^{82}$ Letter of 16 November 1944. 
${ }^{83}$ Letter of 12 December 1944. Żółtowski’s cousin, Jerzy Światopełk Czetwertyński (1907-1977), was arrested and sent to Auschwitz together his brother, father, and uncle on 6 April 1941. His father, Ludwik Światopełk Czetwertyński, died in Auschwitz on 3 May 1941. Jerzy was later sent to Buchenwald, from where he escaped in 1944. He came to England in the autumn of 1944 (PRC Collection 434/224).

${ }^{84}$ Letter of 21 December 1944.

${ }^{85}$ Eliot, "Preface to Roll Call," 582.

${ }^{86}$ Ibid., 584.

${ }^{87}$ Ibid.

${ }^{88}$ Nowa Polska was a left-leaning literary journal launched in London in 1942 and subsidised by the Polish Ministry of Information. It closed down in 1946 when its editor, Antoni Słonimski, was appointed chairman of UNESCO's literature section. In 1943-5, Nowa Polska published several books, including the pamphlet Obóz śmierci (The Camp of Death), which was brought from Poland by an underground courier.

${ }^{89}$ See Margaret Storm Jameson, Journey from the North, vol. 2 (London: Collins\&Harvill, 1970), 147-73.

${ }^{90}$ Kocwa's memoir was originally published in Odrodzenie [Revival] 24 (1945). Other writers Jameson met in Poland included Czesław Miłosz, who had just finished translating The Waste Land into Polish. Jameson recounts Miłosz telling her that "he respected Eliot as a great poet, and the one poet of our time who fused two realities, the sensuous and the metaphysical - which may be what a modern poet must do if he is to tell even part of the truth about an age which contains Picasso, Proust, and the Auschwitz gas chambers." Miłosz asked Jameson to deliver his letter with a request for permission to publish his translation to Eliot on her return to London. Journey from the North, vol. 2, 161. The letter is dated 14 September 1945 and is part of the Faber Collection.

${ }^{91}$ Eugenia Kocwa, "On the Sands of Mecklenburg," The Adelphi 23, no. 3 (April-June 1947): 127-35.

${ }^{92}$ H. A. Hodges, "The Crisis of Western Culture," The Adelphi 23, no. 3 (April-June 1947): 113-8 (115).

${ }^{93}$ Ibid, 116.

94 T. S. Eliot, "Culture and Politics,” The Adelphi 23, no. 3 (April-June 1947): 119-21 (120-1).

95 John Middleton Murry, "The Crisis of Man," The Adelphi 23, no. 3 (April-June 1947): 122-7 (122-3). Interestingly, in the 1930s Murry was a staunch advocate of a Christianised version of communism, which he put forward in The Necessity of Communism (London: Jonathan Cape, 1932). For Murry's ongoing religious debates with Eliot, see also David Goldie, A Critical Difference: T. S. Eliot and John Middleton Murry in English Literary Criticism, 1919-1928 (Oxford: Oxford University Press, 1998); and Joanna Rzepa, "Tradition and Individual Experience: T. S. Eliot's Encounter with Modernist Theology," in Religion and Myth in T.S. Eliot's Poetry, ed. Scott Freer and Michael Bell (Newcastle: Cambridge Scholars, 2016), 99-119.

${ }^{96}$ Jameson, Foreword to Kocwa, "On the Sands of Mecklenburg," 128.

${ }^{97}$ Kocwa, "On the Sands of Mecklenburg," 130.

98 Jameson, Foreword, 128.

${ }^{99}$ J. P. Hogan, "Review of Victor Gollancz's In Darkest Germany and Stefan Schimansky's Vain Victory," The Adelphi 23, no. 3 (April-June 1947): 170-1 (171). In the post-war years, the Christian press in Britain argued that ordinary Germans should not be held accountable for the Nazi crimes. Many prominent Church leaders were critical of the war-crime trials and disapproved of the transfers of the German population from the territories that were incorporated into Poland by the Potsdam Agreement of 1 August 1945. As Lawson points out, "by interpreting the experience of German deportees within the continuum of suffering resulting from war, the Anglican community considered such an experience within the overarching context of a Christian battle against anti-Christianity" (134). See The Church of England and the Holocaust, 139-166. See also Eliot's contribution to an exchange on the deportations of Germans: "Mass Deportations," The Times, October 30, $1945,5$.

${ }^{100}$ Hogan, 171.

${ }^{101}$ Eliot, "Preface to Roll Call," 582.

${ }^{102}$ Lawson, The Church of England and the Holocaust, 133.

103 The October issue contained an apology to the subscribers with an explanation that Nowa Polska did not come out in July, August and September because the British authorities withdrew its paper license.

104 Jameson, Journey, vol. 2, 167. See also Joanna Kuciel-Frydryszak, Stonimski: Heretyk na ambonie [Słonimski: A Heretic at the Pulpit] (Warszawa: WAB, 2012), 189. Słonimski had Jewish roots, though he was raised as a Catholic. He lost most of his family in the war. His eldest brother Adam, who was forced to live in the Piotrków ghetto, killed his family and himself when the Nazis began liquidating the ghetto. The other brother, Piotr, was killed in the Warsaw Rising. Słonimski's niece, Lilka Modzelewska, survived the war, but was then raped and murdered by the Soviet soldiers (Kuciel-Frydryszak, 182, 187).

105 The October issue included Zofia Nałkowska's "Ludzie w Oświęcimiu" [People in Auschwitz], Feliks Topolski's "Notatki z ostatnich dni wojny" [Notes from the Final Years of the War] and Rachela Auerbach's, 
"O przyjaciółce-Polce i o polskich przyjaciołach" [On Polish Girlfriend and on Polish Friends], Nowa Polska 5, no. 1 (October 1945): 14-6, 17-32, 58-62.

106 Although Roll Call does not mention Jews since it was written before the Jewish extermination began, after the suppression of the Warsaw Ghetto Uprising in 1943, Andrzejewski wrote the novella Wielki Tydzien' (Holy Week), which tells the tragic story of a Jewish woman hiding from the Nazis in occupied Warsaw. It was published in English as Holy Week: A Novel of the Warsaw Ghetto Uprising, trans. Oscar Swan (Athens: Ohio University Press, 2007).

107 Jameson, Journey, 167. See also David Engel, "Patterns of Anti-Jewish Violence in Poland, 1944-1946," Yad Vashem Studies 26 (1998): 43-85.

${ }^{108}$ Eliot, "Preface to Roll Call," 582.

${ }^{109}$ See Keith Sword, Deportation and Exile: Poles in the Soviet Union, 1939-48 (Basingstoke: Palgrave, 1994) and Anne Applebaum, Iron Curtain: The Crushing of Eastern Europe 1944-56 (London: Allen Lane, 2012).

${ }^{110}$ Pomian (pseudonym of Bohdan Sałaciński) was a lawyer, journalist and historian. During the war he served in the Home Army and worked in propaganda (Polish Underground Movement Study Trust, TP2/1202).

111 Andrzejewski, Apel (London: Światpol, 1945), 7.

112 Fleming, 270. See also George Sanford, "The Katyn Massacre and Polish-Soviet Relations, 1941-43," Journal of Contemporary History 41, no. 1 (2006): 95-111.

113 Aleida Assmann, "The Holocaust - a Global Memory? Extensions and Limits of a New Memory Community," in Memory in a Global Age: Discourses, Practices and Trajectories, ed. Aleida Assmann and Sebastian Conrad (Basingstoke: Palgrave, 2010), 97-117 (97).

114 Julius, 257. While this paper does not directly consider Julius' argument about Eliot's anti-Semitism, it nevertheless demonstrates the need for more research into what Jonathan Freedman calls "the ethno-racial dynamics of literary modernism," as well as the cultural, political, and religious milieux of the period, which can contribute to a better understanding of the discursive environment that both shaped and was shaped by Eliot's and his contemporaries' writings. Jonathan Freedman, "Lessons Out of School: T. S. Eliot's Jewish Problem and the Making of Modernism,” Modernism/modernity 10, no. 3 (2003): 419-29 (420).

115 Assmann, 97-8. See also Dan Stone, "The Domestication of Violence: Forging a Collective Memory of the Holocaust in Britain, 1945-6," Patterns of Prejudice 33, no. 2 (1999): 13-29.

116 Assmann, 110. 